\title{
Electromobility and electric motor vehicle-basic topics in the management of durable and sustainable development of ecological automotive transports
}

\author{
Gheorghe Neamțu ${ }^{1}$, Aurel Mihail Țîțu ${ }^{2}{ }^{3}$ \\ ${ }^{1}$ Polytechnic University of Bucharest, 54, Splaiul Independenței, Sector 5, Bucharest, \\ Romania \\ ${ }^{2}$ Lucian Blaga University of Sibiu, 10, Victoria Street, Sibiu, Romania \\ ${ }^{3}$ The Academy of Romanian Scientist, 54, Splaiul Independenței, Sector 5, Bucharest, \\ Romania \\ E-mail: geluneamtu@yahoo.com, mihail.titu@ulbsibiu.ro
}

\begin{abstract}
The scientific paper presents a concrete research carried out by the authors with a view to implementing technical concepts, so that those interested in this field can learn about a certain way of exposing their problems with regard to the durable and sustainable development of ecological automotive transports. At the moment, the electric motor vehicle demonstrates its efficiency only in the urban environment. Features related to limited autonomy, the number or power of existing charging stations on the route or at the end of the line, the higher weight of a motor vehicle determined by related equipment (battery pack and related equipment), but also the rather high price on their purchase, make them still unimportant and unattractive among the population.

In this paper we show a technical and managerial study with engineering nuances, through which readers look at and understand the concept of sustainable development in a global context, presenting a SWOT analysis of this type of motor vehicle, but also the characteristics and indicators for assessing their quality, how they influence quality and some corrective measures.

Finally, some conclusions and subsequent research directions are presented in the field approached.

Keywords: electromobility, electric motor vehicle, durable and sustainable development, ecological automotive transport, quality assessment indicators.
\end{abstract}

\section{Introduction}

The sustainable development of automotive transports has always been and remains a special concern of scientists. Durability and sustainability in transport derives from a comprehensive structure that aims to meet travel needs for today's generation, without contaminating or damaging environmental factors or human health.

The new human civilization is rapidly developing in all fields, through a solid exchange of material and intellectual capital, and continually requires the circulation of goods or people from one place to another.

The evolution of the means of travel and the means of transport went simultaneously with the technological development, thus depending on each other. Over time, communication routes and transport systems have become so important that they are an integral part of everyday life. 
Motor vehicles are today the most appreciated means of transport. This is due to the great advantages they offer to users. The dynamics and speed by which material goods, merchandise or persons move into space are added to technology, civilization, comfort and ergonomics. The motor vehicle has become today a great human necessity. Sometimes motor vehicles often prove to be true values, collectible items of inestimable value, owned by those who really know them.

The social division of labour has increased through the evolution of the production forces, and the movement of people and goods has led to a rapid development of transports, so that today they are an independent branch.

"Mobility and transports are important to all of us. From daily commuting to work, visiting family and friends, tourism, to the proper functioning of the global supply chains of shops and our industrial production, mobility is a contributing factor to our economic and social life. The free movement of people and goods across internal borders is one of the fundamental freedoms of the European Union $(E U)$ and its single market. Travelling in the EU has led to increased cohesion and strengthening European identity. As the second largest area of expenditure for European households, the transport sector contributes 5\% to European GDP and directly employs around 10 million workers" [9].

Compared to other sectors of the economy (energy, industry, constructions, etc.), which have taken measures to mitigate pollution since 1990, the transport sector has developed rapidly and chaotically, which has caused pollutant emissions from transport activities to increase and cause significant damage to human nature and health. For this reason, the transport sector has become a major obstacle to the implementation of European objectives in the field of environmental protection and human health. Although in this respect, the world's authorities come up with proposals and draw up laws and regulations on environmental protection (fuel quality standards, emission standards for motor vehicles, the use of cleaner vehicle manufacturing technologies, green, hybrid or electric means of transport, etc.), the quantities of chemicals and waste of any kind that end up in nature are still high.

Natural fossil fuel resources are expected to run out in the next 35-40 years. In this respect, mankind will have to find alternatives for mobility. Alternative fuels will have to replace carbon-based fuels. Globally, environmentally friendly vehicles, hybrid and electric vehicles are growing and growing more and more.

"Although it benefits its users, mobility also entails costs for our society. These costs include greenhouse gas emissions, air, noise and water pollution, as well as road and other accidents, traffic congestion and biodiversity decline, all of which affect our health and well-being. Efforts and policy measures so far have not yet sufficiently addressed these costs. Greenhouse gas emissions in the transport sector have increased over time and currently account for no less than a quarter of the EU total" [9].

Now applying maximum efficiency of the consumption of raw materials and energy, the transport system must meet in optimal conditions the economic, ecological and social prospects of the mobility needs for generations to come.

The hybrid motor vehicle is considered to be the crossing element, the stepping stone, the interface between the classic and the electric vehicle. It is, if we may say, a temporarily viable alternative found by mankind to the classic thermal motor vehicle. Soon the internal combustion engine will be over. The electric engine comes with small but fast steps and it will be in addition to other types of ecofriendly engines (e.g. hydrogen engine - fuel cells), the alternative of the propulsion of the motor vehicles of the future. They will be the pillar of the durable and sustainable development of the road transport system.

Electric motor vehicles, as well as hybrid vehicles, appear in land transport systems as an alternative to conventional vehicles which has become increasingly polluting to the environment.

"As with renewable energy over the past decade, the automotive industry is currently investing heavily in the emergence of technologies for low or zero-emission vehicles, such as electric vehicles" [8]. 
In other words, specialists and researchers have the task of finding current transport variants that do not pollute the environment and that do not affect human health, and this can be achieved by increasing the energy efficiency of the fuels burned in the thermal engines of the means of transport, the use of more fuel-efficient, environmentally friendly, clean vehicles, the use of alternative energies for travel, the orientation of the mobility needs of society towards transport systems other than road transport and last but not least, the use of environmentally friendly intermodal transport, the permanent reduction of waste of any kind resulting from the production or decommissioning of degraded, old, outdated, physically and morally wasted means of transport.

So, humanity is forced to find alternatives for mobility. Technological evolution allows to do so. The key to this problem is the electric vehicle, which is the sustainable and durable solution to the problem of human mobility.

\section{Electric motor vehicle - a step forward for durable and sustainable development of automotive transports}

\subsection{Presentation}

"Today, because of the pollution that the fossil fuel engine produces and the prospect of depleting the reserves of such fuel, we have to turn our attention to the electric engine. In principle, electric engines are extremely powerful and efficient, but the big disadvantage was that motor vehicles equipped with such engines had a low autonomy at first" [2].

As part of the road transport system, the electric vehicle consists of a set of mechanisms, systems, installations, technical organs and parts, all assembled on a frame (chassis/body), arranged on two to four axles, running through four, eight wheels and using as a source of displacement the force of electricity stored in batteries pack, consumed by one or two electric engines, which eliminates zero emissions in the atmosphere.

"A plug-in electric vehicle (PEV) is any vehicle that can be recharged from an external source of electricity, such as wall sockets, and the energy stored in the rechargeable batteries acts or contributes to the wheel's driving. The PEV is a subset of electric vehicles that includes electric, fully electric or battery electric (BEV) vehicles and plug-in hybrid electric vehicles (PHEV)" [3].

The fascinating evolution of the electric motor vehicle is a spectacular one, with many ups and downs throughout history. At the level of the 1900s, this type of vehicles dominated the market, in 1935 they were very rare, and after 90 years they reappear in force, now being a real trend, a fashion for lovers of motor vehicles and the environment. On this date, most vehicle manufacturers in the world manufacture at least one full-electric vehicle model. Mankind has a choice anywhere in the world.

The first electric vehicle appeared in the world in the late 1800s and early 1900s dominated any classic vehicle. In fact, more than four thousand vehicles were running in the US at the time, according to research and up to 30percent of them were electric.

The smell and vibrations produced by conventional motor vehicles using steam or gasoline had become unbearable at the time, and for this reason, people were increasingly interested in the opportunities that arose from the alternative of polluting vehicles. Another reason people refocused was also the ease with which this type of motor vehicles was driven.

Conventional motor vehicles started manually and drivers had to pay more attention to changing gears, which was quite difficult for those times.

Even if steam-powered vehicles did not require manual gear changes, the inconvenience of using this type of vehicle was due to the long time it took to put them into service.

The Wood's Queen Victoria Electric Car, which occurred in the U.S. in 1906, was a much more interesting and viable option for those times. 
The manufacture of the electric motor vehicle reached its peak in 1912, eight years later the manufacturers of electric vehicles achieving fantastic results with them.

However, the technology of the motor vehicle at that time was quite expensive, as now, not everyone could afford it, and interest in this niche decreased. There was then a total abstinence of the public dream of this type of motor vehicle.

It was only after the 1960s and 1970s that the electric motor vehicle returned interesting again, after the policies of global environmental organizations such as the Clean Air Act, and so on, requiring the state authorities of the world to take action and set standards on air quality and the environment, demanding clear deadlines for the implementation of the relevant legislation. All this was also amplified by OPEC's oil embargo in 1973, which caused the oil price to rise substantially.

Here are two reasons why mankind has had to look for alternatives to transportation.

In this regard, in 1976, the U.S. Congress authorized the Department of Energy to support researchers in the development of technology for hybrid and electric vehicles. So many ideas were put into action, which were developed and subsequently implemented. Around the world, leading manufacturers are investing large financial funds to create and develop models, and the big German vehicle manufacturer BMW presents the prototype of an electric vehicle in Munich at the 1972 Summer Olympic Games.

The 1970s were quite creative from this point of view, many such vehicles appeared on the market, but these models remained unpurchased, because they were limited in terms of speed, the autonomy of the electric batteries that propelled them and the comfort that is not that should be. By 1989 their popularity was down, but since 1990, the legislation on polluting emissions has made electric vehicle temporarily recover. In the U.S., General Motors creates more than a thousand units of the EV1 model, which had an autonomy of $160 \mathrm{~km}$, and were only available in rented form for residents of California, Arizona and Georgia.

However, it seems that even this time the population was not impressed by these vehicles, and on the expiry of the leases the company decided to dismantle vehicles, keeping 40 copies that were donated to institutions and museums.

However, in the following years, electric models were manufactured under an impressive number of millions by General Motors, Nissan and Volkswagen, with the trend of growth. Since 2016, these manufacturers have launched six new models of electric vehicles on the market.

Coming back to the present time, Tesla is proposing new, reliable and powerful high-tech electric engines, which will be mounted on the Faraday Future prototype, as well as electric batteries for propulsion, with a high autonomy of 400-480 km, which have been put in operation since 2020 .

Experts estimate that " the electric vehicle market will grow from $2 \%$ of the global share for 2016 to $22 \%$ in 2030." [2].

Even today, in full development, it seems that the durability of the electric motor vehicle is staggering a little.

This is determined by the multitude of factors involved in electromobility, which act in their own way and still have something to say.

Despite the advanced technologies that electric vehicles guarantee, they still have problems with the rather high purchase price.

We can say that prices start at the value of EUR 22.000, an amount in exchange for which you can purchase an electric vehicle with a power equivalent to 80-150 HP and a minimum autonomy of 150 $\mathrm{km}$. Crossing the threshold of EUR 40.000 brings access to an autonomy that exceeds $300 \mathrm{~km}$, and performance models, which also offer a sporty start, cost more than EUR 50.000. 
Table 1. SWOT analysis of electric motor vehicles

Strengths (Strong-S)

\begin{tabular}{l} 
S. Strengths \\
\hline $\begin{array}{l}\mathrm{S}_{1} \text {. Very environmentally friendly - zero } \\
\text { noxious emissions into the atmosphere; }\end{array}$ \\
$\mathrm{S}_{2}$. Simple power supply - they can be
\end{tabular}
supplied with electricity from a household outlet (if charger feeder is also purchased);

\section{Consolidation/development proposals}

- Use of electricity supply only from renewable sources;

- Use of low-noise tires in operation;

- Use of modern, clean manufacturing technologies;

- Use of environmentally friendly raw materials and manufacturing materials (plastics, light metals, etc.);

- Informing and educating the population.

- Financial facilities for the purchase of electricity chargers at home;

- Increase the battery life of electric batteries;

$\mathrm{S}_{3}$. Low operating costs - do not use conventional fuels for propulsion, they are totally electric;

$\mathrm{S}_{4}$. High efficiency - very low failure rate, low number of parts under the action of friction forces;

- Increase deadlines/times for carrying out revisions and technical maintenance and other maintenance work;

- Extension of the warranty period.

$\mathrm{S}_{5}$. Attractive eco-bonuses are granted when purchasing such a new vehicle - the legislative policy of environmental protection specific to each country;

- Strengthening environmental legislation;

- Maintaining eco-bonuses;

- Other tax facilities (free parking, electricity subsidies, low-priced maintenance works, etc.);

- Informing the population.

$\mathrm{S}_{6}$. Increased traction power - electric engines reach maximum speed in a short time;

$\mathrm{S}_{7}$. Not require maintenance and diagnostic work of high complexity - they have a small number of equipment to be diagnosed;

- Improving the technical performance of electric engines

- Development of the network of service units;

- Training of specialists in the field of electromobility and maintenance of electric motor vehicles;

- Continuous training of specialists in the field of electric vehicles.

$\mathrm{S}_{8}$. Extremely silent - electric engines do not produce vibrations or noises;

- Require sound generators;

- Informing the population.

- Increase the storage capacity of electric batteries;

- More powerful and efficient electric generators.
S. $_{9}$ Recover energy - they charge when braking, especially in urban traffic where decelerations are very common; 
Volume 3, Issue 2, 2021

ISSN: 2668-0416

Thoth Publishing House

\section{S. Strengths}

$\mathrm{S}_{10}$. Low-cost maintenance - electric engines do not require maintenance work;

$S_{11}$. Fast depreciation of the high purchase cost - the electricity used for propulsion is very cheap;

$\mathrm{S}_{12}$. Constructively eliminate certain organs in the transmission - they do not have a clutch and gearbox, the torque - speed feature of electric engines ensuring power at any speed in the dynamics of the vehicle.

\section{Consolidation/development proposals}

- Equipping service units with diagnostic and control equipment, SDVs;

- Informing and educating the population.

- Informing, stimulating and educating the population;

- Maintaining or lowering the price of electricity.

- Increase the capacity, power and battery life of accumulators;

- Decrease in the purchase price of the motor vehicle;

- Informing the population;

- Removal from the transmission and other elements (e.g. main and final transmission in $4 \times 4$ vehicles and trucks).

Table 2. SWOT analysis of electric motor vehicles

Weaknesses (Weak-W)

\section{W. Weaknesses}

$\mathrm{W}_{1}$. Low-travel autonomy on the electric module $(480 \mathrm{~km})$ - the electric traction battery is consumed quickly, depending on the load, season and use of the vehicle;

$\mathrm{W}_{2}$. They are dependent on specialized energy supply infrastructure - in some states the infrastructure is deficient;

$\mathrm{W}_{3}$. Slow charging of electric batteries traction batteries reach maximum load capacity in 0.5-12 hours, producing syncope in the transport;

$\mathrm{W}_{4}$. High cost of replacement traction batteries - traction battery made of expensive materials and technologies;

$\mathrm{W}_{5}$. High purchase price - state-of-the-art electrical technology;

\section{Disposal measures}

- Design and development of more efficient, cheaper, high-capacity electric batteries;

- Location and development of electricity charging infrastructure in all car parks, on all European streets and roads;

- Location and development of supply infrastructure in the parking lots of blocks and large shops.

- Equipping all charging points with powerful power stations (100kw; 400-500 Vcc).

- Decrease in price per $1 / \mathrm{kwh}$ for electric batteries;

- Use of cheaper and high-quality materials in the manufacture of electric batteries;

- Develop new technologies regarding electric batteries.

- The maintenance by the authorities of the European states of measures to stimulate the population when purchasing an electric motor vehicle (eco-bonuses);

- Decrease in price per $1 / \mathrm{kwh}$ for electric batteries. 


\section{W. Weaknesses}

$\mathrm{W}_{6}$. They need investments to provide the supply and service infrastructure - highpower power stations.

\section{Disposal measures}

- Allocation by the authorities of their financial funds for the development of infrastructure for the supply of electricity;

- Gradual transition from the classical power stations to partial equipment with electric power stations;

- Development of service units dedicated to this type of vehicle, equipping them with specific logistics, training of service personnel.

Table 3. SWOT analysis of electric motor vehicles

Opportunities (Opportunities-O)

\begin{tabular}{l} 
O. Opportunities \\
\hline $\mathrm{O}_{1}$. Global heating - the elimination of \\
noxious substances into the atmosphere by \\
conventional vehicles destroyed the ozone \\
layer;
\end{tabular}

$\mathrm{O}_{2}$. Evolution of the technology - they benefit from the latest technological breakthroughs;

$\mathrm{O}_{3}$. Represent the product of certain research - substantial funds invested in research;

$\mathrm{O}_{4}$. Environmental legislation environmental legislation prohibits the use of polluting, environmentally unfriendly vehicles;

O5. Zero taxes and fees - local public authorities provide incentives to encourage people to purchase this type of motor vehicles;

O6. They can circulate in areas or cities that prohibit the movement of motor vehicles with classic engine - do not pollute the environment;

\section{Development/efficiency measures}

- The decrease in the minimum amount of the pollution standard for motor vehicles with internal combustion engines;

- Development of new technologies in the field of electromobility, safety, ergonomics and comfort of electric motor vehicles.

- Continued research in the development of technologies in the field of electromobility, safety, ergonomics and comfort of electric motor vehicles;

- Allocating the necessary resources for research in this area.

- Strengthening environmental legislation;

- Exemption from payment of annual taxes and fees to the local authorities;

- Granting substantial eco-bonuses when purchasing a new motor vehicle;

- Free and dedicated parking spaces equipped with filling stations in large car parks or in the parking lots of cities or large shops;

- Prohibition of entry and circulation by internal combustion motor vehicles, under a certain pollution standard, in the central area of major cities or urban metropolises. 
Table 4. SWOT analysis of electric motor vehicles

Threats (Threats-T)

\begin{tabular}{|c|c|}
\hline T. Threats & Mitigation / reduction / counteracting measures \\
\hline $\begin{array}{l}T_{1} \text {. Energy crisis - rising electricity prices } \\
\text { will make this type of vehicle inefficient; }\end{array}$ & $\begin{array}{l}\text { Maintaining or lowering the price of electricity; } \\
\text { - Development of alternative renewable energies. }\end{array}$ \\
\hline $\begin{array}{l}\mathrm{T}_{2} \text {. The financial crisis creates the disinterest } \\
\text { of customers in the purchase of these } \\
\text { vehicles - high purchase price, low standard } \\
\text { of living of the population, failure by the } \\
\text { authorities to grant substantial eco-bonuses; }\end{array}$ & $\begin{array}{l}\text { - GDP growth per capita; } \\
\text { - Increasing the standard of living and purchasing } \\
\text { power of the population; } \\
\text { - Keeping the leu/currency ratio as close as possible; } \\
\text { - Measures to stop the growth of the currency on the } \\
\text { interbank market. }\end{array}$ \\
\hline
\end{tabular}

\section{Indicators for assessing the quality of 'green' motor vehicles}

Analyzed by the spectrum of technology, ecological motor vehicles are constructively equipped with installations, systems and applications that contribute to the increased comfort, ergonomics and safety of drivers, passengers, pedestrians and cyclists, all road users. All this contributes to the increase in the quality of green motor vehicles and their transport services.

The expected quality of transport services with 'green' motor vehicles refers to the level of quality that customers receiving transport services (goods or passengers) want explicitly or implicitly.

For example, "in the field of public passenger transport, the quality of the service is reflected by passengers' perception of the performance of the transport service. Indicators related to the performance of the service describing these perceptions are different from the economic indicators used by transport companies, but also from those used by designers. The quality of services depends to a large extent on the strategic, tactical and operational decisions applied in the public transport system, depending on the budget limits. These decisions relate in particular to the establishment of public transport routes, the frequency and period of the day in which services are offered, the type of services offered. The quality of service is an indicator of the success of a public transport operator, which has direct implications for passengers" [4].

In this respect, we agree with the authors and argue that in order to provide quality services to customers or travellers, organizations and the road transport system must apply according to certain quality requirements.

Propulsion systems that set vehicles in motion have a particular importance for road transport.

The electric propulsion system, and then the hybrid propulsion system, were an older concern of automotive specialists and researchers.

Given the contribution of science, technology and innovation, these two systems have today reached an advanced stage of development, so that they have achieved the same performances, and sometimes even surpassed the classical propulsion systems of road vehicles.

Although the mobility needs of the population are increasing, in the near future the propulsion of motor vehicles provided by conventional engines will disappear.

The end of the classic propulsion will occur with the widespread application of transport decarbonization programmes throughout the world, then with the end of energy resources based on fossil fuels.

The classic solution of motor vehicle engines will be replaced and provided by electric engines, which are in full development.

Lately, the electric propulsion of means of transport has become a concern of all research and development centers and departments within the world's major automotive manufacturers.

The ergonomics and comfort of the motor vehicle, the assistance and communication systems of the driver with the motor vehicle and the road transport system, the information systems of the driver 
and passengers, the reliability and high maintenance, are just some of the characteristics of the quality assessment.

If the environmental qualities of electric motor vehicles are added to these characteristics, characterized by zero gas emissions to the exhaust pipe and quietness in operation, this motor vehicle fully meets the user's implicit and explicit needs.

All these characteristics are defined by attributes that determine the quality indicators of "green" non-polluting motor vehicles. We propose this definition in order to be able to make an assessment of the "green" ecological means of transport.

Quality indicators are defined by the way in which an electric motor vehicle satisfies the degree of waiting of the driver (user or owner), the customer or the passenger (beneficiary of the transport service) within a certain period of time. In this case, the period of time can be interpreted as: the entire life cycle of the motor vehicle, the period of ownership by the owner, a journey on a particular route or travel itinerary, a transport of goods, etc.

Quality indicators is the totality of a set of attributes that define the electric motor vehicle and which are actually based and defined by the systems and installations that contribute and enhance their ergonomics, safety and comfort.

In Table 3.1 we present the main indicators of the quality of "green" motor vehicles, the qualitative requirement to which the quality indicator relates, how it influences the expected quality of the road transport service and the corrective measures to be taken for compliance.

Table 2. Indicators of assessment of the quality of 'green' motor vehicles, the requirement to which the quality indicator relates, how it influences the expected quality of the road transport service and the corrective measures to be taken for compliance.

\begin{tabular}{|c|c|c|c|c|}
\hline \multirow[t]{2}{*}{ Quality indicator } & \multirow{2}{*}{$\begin{array}{l}\text { Requirement } \\
\text { to which the } \\
\text { quality } \\
\text { indicator } \\
\text { relates }\end{array}$} & \multicolumn{2}{|c|}{$\begin{array}{l}\text { How the quality } \\
\text { indicator influences the } \\
\text { expected quality of the } \\
\text { road transport service }\end{array}$} & \multirow[t]{2}{*}{ Corrective measurements } \\
\hline & & Positive & $\begin{array}{l}\text { Negativ } \\
\text { e }\end{array}$ & \\
\hline \multicolumn{5}{|c|}{ A. Technical quality indicators } \\
\hline Electric battery life & $\begin{array}{l}\text { Regularity, } \\
\text { rhythmicity and } \\
\text { punctuality of } \\
\text { the means of } \\
\text { transport; } \\
\text { Travellers' } \\
\text { comfort. }\end{array}$ & If it is high & $\begin{array}{l}\text { If it is } \\
\text { low }\end{array}$ & $\begin{array}{c}\text { It is directly influenced by } \\
\text { the capacity of the electric } \\
\text { battery. } \\
\text { Development of electric } \\
\text { batteries with a higher } \\
\text { battery life. }\end{array}$ \\
\hline $\begin{array}{l}\text { Electric battery } \\
\text { capacity }\end{array}$ & $\begin{array}{l}\text { Regularity, } \\
\text { rhythmicity and } \\
\text { punctuality of } \\
\text { the means of } \\
\text { transport; } \\
\text { Travellers' } \\
\text { comfort. }\end{array}$ & If it is high & $\begin{array}{l}\text { If it is } \\
\text { low }\end{array}$ & $\begin{array}{l}\text { Development of electric } \\
\text { batteries with a higher } \\
\text { capacity. }\end{array}$ \\
\hline $\begin{array}{l}\text { Charging time of the } \\
\text { electric battery }\end{array}$ & $\begin{array}{l}\text { Regularity, } \\
\text { rhythmicity and } \\
\text { punctuality of } \\
\text { the means of } \\
\text { transport; } \\
\text { Travellers' }\end{array}$ & $\begin{array}{l}\text { If they are } \\
\text { minimal }\end{array}$ & $\begin{array}{l}\text { If they } \\
\text { are } \\
\text { maximu } \\
\text { m }\end{array}$ & $\begin{array}{l}\text { Equipping power points } \\
\text { with high power charging } \\
\text { stations (50-100 kw/400- } \\
500 \mathrm{Vcc} / 100-400 \mathrm{~A}) \text {. } \\
\text { "Charging times decrease } \\
\text { from } 15 \text { h to } 29 \text { min." [7]. }\end{array}$ \\
\hline
\end{tabular}


Volume 3, Issue 2, 2021

ISSN: 2668-0416

Thoth Publishing House

\begin{tabular}{|c|c|c|c|c|}
\hline \multirow[t]{2}{*}{ Quality indicator } & \multirow{2}{*}{$\begin{array}{l}\text { Requirement } \\
\text { to which the } \\
\text { quality } \\
\text { indicator } \\
\text { relates }\end{array}$} & \multicolumn{2}{|c|}{$\begin{array}{l}\text { How the quality } \\
\text { indicator influences the } \\
\text { expected quality of the } \\
\text { road transport service }\end{array}$} & \multirow[t]{2}{*}{ Corrective measurements } \\
\hline & & Positive & $\begin{array}{c}\text { Negativ } \\
\text { e }\end{array}$ & \\
\hline $\begin{array}{c}\text { Power of electric } \\
\text { traction } \\
\text { engine/engines }\end{array}$ & $\begin{array}{l}\text { comfort. } \\
\text { Regularity, } \\
\text { rhythmicity and } \\
\text { punctuality of } \\
\text { the means of } \\
\text { transport; } \\
\text { Travellers' } \\
\text { comfort. }\end{array}$ & $\begin{array}{l}\text { If they have } \\
\text { high power }\end{array}$ & $\begin{array}{l}\text { If they } \\
\text { have low } \\
\text { power }\end{array}$ & $\begin{array}{l}\text { Equipping electric vehicles } \\
\text { with engines with power to } \\
\text { ensure an appropriate } \\
\text { weight-traction ratio. }\end{array}$ \\
\hline Vehicle weight & $\begin{array}{l}\text { Regularity, } \\
\text { rhythmicity and } \\
\text { punctuality of } \\
\text { the means of } \\
\text { transport; } \\
\text { Travellers' } \\
\text { comfort; } \\
\text { Road safety. }\end{array}$ & If it is low & $\begin{array}{l}\text { If it is } \\
\text { high }\end{array}$ & $\begin{array}{l}\text { Hybrid and electric means } \\
\text { of transport have a higher } \\
\text { weight due to additional } \\
\text { equipment (electric } \\
\text { engine/engines, electric } \\
\text { accumulators, electrical and } \\
\text { electronic command and } \\
\text { control elements of electric } \\
\text { engines, other related } \\
\text { elements. } \\
\text { Use of light-weight } \\
\text { materials in the } \\
\text { construction of hybrid or } \\
\text { electric motor vehicles (e.g. } \\
\text { aluminium, titanium, } \\
\text { carbon, plastics, etc.) }\end{array}$ \\
\hline \multicolumn{5}{|c|}{ B. Quality indicators of active safety } \\
\hline $\begin{array}{l}\text { All categories of } \\
\text { airbags for the } \\
\text { protection of } \\
\text { passengers, } \\
\text { pedestrians and other } \\
\text { vulnerable persons }\end{array}$ & $\begin{array}{l}\text { Safety and } \\
\text { comfort of } \\
\text { passengers, } \\
\text { pedestrians and } \\
\text { other } \\
\text { vulnerable } \\
\text { persons }\end{array}$ & $\begin{array}{l}\text { If there are } \\
\text { maximum } \\
\text { facilities }\end{array}$ & $\begin{array}{l}\text { If there } \\
\text { are } \\
\text { minimu } \\
\text { m } \\
\text { facilities }\end{array}$ & Standard equipment. \\
\hline $\begin{array}{l}\text { Other elements and } \\
\text { active safety systems } \\
\text { other than the } \\
\text { standard ones } \\
\text { provided for in } \\
\text { Regulation (EU) } 858 \\
\text { of May } 30,2018\end{array}$ & $\begin{array}{l}\text { Safety and } \\
\text { comfort of } \\
\text { passengers, } \\
\text { pedestrians and } \\
\text { other } \\
\text { vulnerable } \\
\text { persons }\end{array}$ & $\begin{array}{l}\text { If provided } \\
\text { outside the } \\
\text { standard }\end{array}$ & $\begin{array}{c}\text { If not } \\
\text { provided }\end{array}$ & $\begin{array}{l}\text { Inclusion in standard active } \\
\text { safety systems and other } \\
\text { safety elements or systems } \\
\text { (e.g. led headlamps with } \\
\text { self-leveling and automatic } \\
\text { long phase; rear vehicle } \\
\text { traffic warning system - } \\
\text { Rear Cross Traffic Alert - } \\
\text { RCTA; panoramic View } \\
\text { Monitor - PVM; parking } \\
\text { assistance with panoramic }\end{array}$ \\
\hline
\end{tabular}


Volume 3, Issue 2, 2021

ISSN: 2668-0416

Thoth Publishing House

\begin{tabular}{|c|c|c|c|c|}
\hline \multirow[t]{2}{*}{ Quality indicator } & \multirow{2}{*}{$\begin{array}{l}\text { Requirement } \\
\text { to which the } \\
\text { quality } \\
\text { indicator } \\
\text { relates }\end{array}$} & \multicolumn{2}{|c|}{$\begin{array}{l}\text { How the quality } \\
\text { indicator influences the } \\
\text { expected quality of the } \\
\text { road transport service }\end{array}$} & \multirow[t]{2}{*}{ Corrective measurements } \\
\hline & & Positive & $\begin{array}{l}\text { Negativ } \\
\text { e }\end{array}$ & \\
\hline & & & & $\begin{array}{l}\text { view; intelligent front and } \\
\text { rear parking sensors with } \\
\text { ICS automatic braking; } \\
\text { blind spot monitoring } \\
\text { system - BSM, etc.) }\end{array}$ \\
\hline & \multicolumn{4}{|c|}{ C. Quality indicators of ergonomics and comfort } \\
\hline $\begin{array}{l}\text { Intuitive positioning of } \\
\text { controls, batteries, } \\
\text { switches, alarms and } \\
\text { optical signals }\end{array}$ & $\begin{array}{l}\text { Driver's } \\
\text { comfort; } \\
\text { Road safety. }\end{array}$ & $\begin{array}{l}\text { If arranged } \\
\text { ergonomically }\end{array}$ & $\begin{array}{l}\text { If not } \\
\text { ergonom } \\
\text { ically } \\
\text { arranged }\end{array}$ & $\begin{array}{l}\text { Mounting all the elements } \\
\text { that contribute to the } \\
\text { comfort of the driver and } \\
\text { the safety of the vehicle, so } \\
\text { that they are easily visible, } \\
\text { are intuitively operated, } \\
\text { without distracting the } \\
\text { driver from the road and } \\
\text { without altering his/her } \\
\text { body position. }\end{array}$ \\
\hline $\begin{array}{l}\text { The level of sound } \\
\text { emitted by audible } \\
\text { warning devices }\end{array}$ & $\begin{array}{l}\text { Driver's } \\
\text { comfort; } \\
\text { Road safety. }\end{array}$ & $\begin{array}{l}\text { If they have } \\
\text { low signal } \\
\text { and are } \\
\text { pleasing to } \\
\text { the ear }\end{array}$ & $\begin{array}{l}\text { If they } \\
\text { have a } \\
\text { strong } \\
\text { signal } \\
\text { and are } \\
\text { disturbin } \\
\text { g to } \\
\text { hearing } \\
\text { or cause } \\
\text { discomf } \\
\text { ort }\end{array}$ & $\begin{array}{l}\text { Equipping means of } \\
\text { transport with sound } \\
\text { warning devices with } \\
\text { pleasant sound, having an } \\
\text { acoustic level } \\
\text { corresponding to the } \\
\text { perception of the human ear } \\
\text { in any situation. }\end{array}$ \\
\hline $\begin{array}{l}\text { Noise level produced } \\
\text { by electric vehicles } \\
\text { during operation/run }\end{array}$ & $\begin{array}{l}\text { Safety of } \\
\text { vulnerable } \\
\text { persons } \\
\text { (pedestrians, } \\
\text { cyclists, } \\
\text { motorcyclists, } \\
\text { other road } \\
\text { users). }\end{array}$ & $\begin{array}{l}\text { If they emit } \\
\text { noise }\end{array}$ & $\begin{array}{l}\text { If they } \\
\text { don't } \\
\text { emit } \\
\text { noise }\end{array}$ & $\begin{array}{l}\text { Equipping hybrid and } \\
\text { electric road transport } \\
\text { means with sound } \\
\text { generators (noise) }\end{array}$ \\
\hline \multicolumn{5}{|c|}{ D. Reliability indicators [11]. } \\
\hline $\begin{array}{l}\text { Probability of proper } \\
\text { operation of the } \\
\text { engine(s), electric } \\
\text { battery and related } \\
\text { electrical and } \\
\text { electronic elements. } \\
\text { R(t) }\end{array}$ & $\begin{array}{l}\text { Regularity, } \\
\text { rhythmicity and } \\
\text { punctuality of } \\
\text { the means of } \\
\text { transport; } \\
\text { Comfort and } \\
\text { safety of }\end{array}$ & $\begin{array}{c}R(t)=p(t)= \\
\operatorname{Prob}(t>T) \\
{[11] .}\end{array}$ & $\begin{array}{l}R(t)= \\
p(t)= \\
\operatorname{Prob}(t \\
<T) \\
{[11]}\end{array}$ & $\begin{array}{c}\text { Use of high-quality } \\
\text { materials in the } \\
\text { construction of motor } \\
\text { vehicles, organs, } \\
\text { subassemblies and spare } \\
\text { parts; } \\
\text { Proper operation of the }\end{array}$ \\
\hline
\end{tabular}


Volume 3, Issue 2, 2021

ISSN: 2668-0416

Thoth Publishing House

\begin{tabular}{|c|c|c|c|c|}
\hline \multirow[t]{2}{*}{ Quality indicator } & \multirow{2}{*}{$\begin{array}{c}\text { Requirement } \\
\text { to which the } \\
\text { quality } \\
\text { indicator } \\
\text { relates }\end{array}$} & \multicolumn{2}{|c|}{$\begin{array}{l}\text { How the quality } \\
\text { indicator influences the } \\
\text { expected quality of the } \\
\text { road transport service }\end{array}$} & \multirow[t]{2}{*}{ Corrective measurements } \\
\hline & & Positive & $\begin{array}{c}\text { Negativ } \\
\text { e }\end{array}$ & \\
\hline & $\begin{array}{l}\text { passengers and } \\
\text { other } \\
\text { vulnerable } \\
\text { persons; } \\
\text { Road safety }\end{array}$ & & & $\begin{array}{c}\text { motor vehicle (application } \\
\text { of a non-aggressive driving } \\
\text { mode); } \\
\text { Performing maintenance } \\
\text { work at the times stipulated } \\
\text { by the manufacturer. }\end{array}$ \\
\hline $\begin{array}{c}\text { Probability of failure } \\
\text { of the engine(s), } \\
\text { electric battery and } \\
\text { related electrical and } \\
\text { electronic elements. } \\
\text { F(t) }\end{array}$ & $\begin{array}{l}\text { Regularity, } \\
\text { rhythmicity and } \\
\text { punctuality of } \\
\text { the means of } \\
\text { transport; } \\
\text { Comfort and } \\
\text { safety of } \\
\text { passengers and } \\
\text { other } \\
\text { vulnerable } \\
\text { persons; } \\
\text { Road safety }\end{array}$ & $\begin{array}{c}F(t) \operatorname{Prob} \\
(t<T) \\
{[11] .}\end{array}$ & $\begin{array}{l}F(t) \\
\text { Prob } \\
(t>T) \\
{[11] .}\end{array}$ & $\begin{array}{c}\text { Use of high-quality } \\
\text { materials in the } \\
\text { construction of motor } \\
\text { vehicles, organs, } \\
\text { subassemblies and spare } \\
\text { parts; } \\
\text { Proper operation of the } \\
\text { motor vehicle (application } \\
\text { of a non-aggressive driving } \\
\text { mode); } \\
\text { Performing maintenance } \\
\text { work at the times stipulated } \\
\text { by the manufacturer. }\end{array}$ \\
\hline $\begin{array}{l}\text { Rate (intensity) of } \\
\text { failure of the } \\
\text { engine/engines, } \\
\text { electric battery and } \\
\text { related electrical and } \\
\text { electronic elements. } \\
\mathrm{z}(\mathrm{t})\end{array}$ & $\begin{array}{l}\text { Regularity, } \\
\text { rhythmicity and } \\
\text { punctuality of } \\
\text { the means of } \\
\text { transport; } \\
\text { Comfort and } \\
\text { safety of } \\
\text { passengers and } \\
\text { other } \\
\text { vulnerable } \\
\text { persons; } \\
\text { Road safety }\end{array}$ & $\begin{array}{l}\text { Low failure } \\
\text { rate } \\
\mathrm{z}(\mathrm{t})<\end{array}$ & $\begin{array}{l}\text { High } \\
\text { failure } \\
\text { rate } \\
\mathrm{z}(\mathrm{t})>\end{array}$ & $\begin{array}{c}\text { Proper operation of the } \\
\text { motor vehicle (application } \\
\text { of a non-aggressive driving } \\
\text { mode); } \\
\text { Performing maintenance } \\
\text { work at the times stipulated } \\
\text { by the manufacturer; } \\
\text { Use of high-quality } \\
\text { materials in the } \\
\text { construction of motor } \\
\text { vehicles, organs, } \\
\text { subassemblies and spare } \\
\text { parts; }\end{array}$ \\
\hline $\begin{array}{l}\text { Average operating } \\
\text { times of } \\
\text { engine/engines, } \\
\text { electric battery and } \\
\text { related electrical and } \\
\text { electronic elements } \\
\text { M.T.B.F. = m }\end{array}$ & $\begin{array}{l}\text { Regularity, } \\
\text { rhythmicity and } \\
\text { punctuality of } \\
\text { the means of } \\
\text { transport; } \\
\text { Comfort and } \\
\text { safety of } \\
\text { passengers and } \\
\text { other }\end{array}$ & $\begin{array}{l}\text { If it is high } \\
\text { M.T.B.F. } \\
\quad=\mathrm{m}>\end{array}$ & $\begin{array}{l}\text { If it is } \\
\text { low } \\
\text { M.T.B.F } \\
\quad \cdot \\
=\mathrm{m}<\end{array}$ & $\begin{array}{c}\text { Proper operation of the } \\
\text { motor vehicle (application } \\
\text { of a non-aggressive driving } \\
\text { mode); } \\
\text { Performing maintenance } \\
\text { work at the times stipulated } \\
\text { by the manufacturer; } \\
\text { Use of high-quality } \\
\text { materials in the }\end{array}$ \\
\hline
\end{tabular}


Volume 3, Issue 2, 2021

ISSN: 2668-0416

Thoth Publishing House

\begin{tabular}{|c|c|c|c|c|}
\hline \multirow[t]{2}{*}{ Quality indicator } & \multirow{2}{*}{$\begin{array}{c}\text { Requirement } \\
\text { to which the } \\
\text { quality } \\
\text { indicator } \\
\text { relates }\end{array}$} & $\begin{array}{r}\text { How th } \\
\text { indicator ir } \\
\text { expected } q \\
\text { road trans }\end{array}$ & $\begin{array}{l}\text { lality } \\
\text { ences the } \\
\text { ty of the } \\
\text { service }\end{array}$ & \multirow[t]{2}{*}{ Corrective measurements } \\
\hline & & Positive & $\begin{array}{l}\text { Negativ } \\
\text { e }\end{array}$ & \\
\hline & $\begin{array}{l}\text { vulnerable } \\
\text { persons; } \\
\text { Road safety }\end{array}$ & & & $\begin{array}{c}\text { construction of motor } \\
\text { vehicles, organs, } \\
\text { subassemblies and spare } \\
\text { parts; }\end{array}$ \\
\hline
\end{tabular}

\section{Conclusions}

The classic motor vehicle has reached its peak. More and more states are prohibiting the use of polluting motor vehicles. The imposition of increasing taxes and fees for the use of such vehicles, the prohibition of access of vehicles with diesel engines with a certain class of pollution (euro 1-4) in certain areas of major European cities is not random, but it is a reality.

The electric motor vehicle has the opportunity to develop, but it has many years to reach its peak. It is growing fast. This will only happen if the technology evolves rapidly and other sources or methods of mobility are discovered. There is some reluctance of people to purchase it. This reluctance is fueled by the reduced battery life, the lack of charging points for electric batteries in some European countries, the higher weight of these vehicles due to additional electrical equipment and the high purchase price;

The reorientation of the population to meet their transport needs is essential and it can also be achieved by using "green" vehicles (scooters, bicycles, minibuses and hybrid or electric buses, trams, trolleybuses, etc.), especially in urban areas;

Tightening the national and European environmental legislation on noxious substances released by internal combustion engines of motor vehicles;

At the moment, it is very important to continue to maintain measures to stimulate the population of the EU Member States, with priority the poorly or mediumly developed, but also those which are highly developed from a social and industrial point of view, for the purchase of ecological motor vehicles, while reducing the support measures when purchasing classic motor vehicles;

At the level of European states, especially in Eastern European countries, rapid and massive investment in the infrastructure of electric motor vehicle service is also needed;

The characteristics and performance specific to "green" motor vehicles, which decrease the quality of road transport services, are as follows:

$>$ Autonomy and charging time of the electric battery;

$>$ High price for the purchase of electric motor vehicles;

$>$ Existence, number and power of charging stations;

$>$ The weight of the vehicle higher as a result of the additional electrical equipment (electric battery and related command and control equipment);

The technical characteristics and performance of 'green' non-polluting motor vehicles are defined by attributes setting out their quality indicators. Quality indicators are defined by the way in which an electric motor vehicle satisfies the waiting level of the driver (user or owner), the customer or passenger (beneficiary of the transport service) within a certain period of time. In this case, the period of time can be interpreted as: the entire life cycle of the motor vehicle, the period of ownership by the owner, a journey on a particular route or travel itinerary, a transport of goods, etc. Quality indicators are the totality of a set of attributes that define the ecological motor vehicle and are actually based and defined by the systems and installations that contribute to and increase their ergonomics, safety and comfort. 


\section{References}

[1] Auto \& Mobility Trends in 2019 CB Insights Research accessed via https://www.cbinsights.com/research/report/auto-mobility-trends-2019/;

[2] Boncu S, Holman A 2010 Traffic and urban environment sustainability Social Psichology Journal article Issue 25, 87-101

[3] David B S 2009 Plug-In Electric Vehicles What Role for Washington? (ed. 1st)" The Brookings Institution 2-5 ISBN 978-0-8157-0305-1 See definition on $\mathrm{p} 2$

[4] Dragu V, Roman C V2012 Specific aspects of quality in urban public transport Life and activities in large urban agglomeration. Bucharest present and future Works of the 7th edition of the Academic Days of the Romanian Academy of Technical Sciences Conference Proceedings Bucharest October 11-12 2012 pp 217-225 [5]

[5] Eckermann E 2001 World History of the Automobile (illustrated ed.) (P. s. Society of Automotive Engineers Ed

[6] Ehsani M, Gao Y \& Gay S 2005 Modern Electric, Hybrid Electric and Fuel Cell Vehicles Fundamentals Theory and Design CRC Press Ed

[7] Noon M 2012 Electric vehicles in urban Europe EVUE- approaches to e-mobility infrastructure Urb Act - We connect cities-We build successes EU - Stakeholder Guide European Regional Development Fund Brussels pp 1-88

[8] The European Commission 2018 A clean planet for everyone. A long-term strategic European vision for a prosperous, modern Competitive and climate-neutral economy Communication from the Commission to the European Parliament the Council the European Economic and Social Committee and the Committee of the Region Report COM773 final

[9] The European Commission 2020 The strategy for sustainable and smart mobility - putting European transport on the path to the future Communication from the Commission to the European Parliament the Council the European Economic and Social Committee and the Committee of the Region Report COM(2020) 789 final-SWD (2020) 331 final 19122020

[10] Tessien R 2018 EVs Oil And ICE Impact By 2023 And Beyon Retrieved February 122021 from Global car sales electric November 28 accessed via https://seekingalpha.com/article/4225153-evs-oil-and-ice-impact-2023-and-beyond

[11] Tîțu M 2008 Reliability and Maintenance AGIR Publishing House Bucharest pp 184-186 